\title{
Microzooplankton biomass distribution in Terra Nova Bay, Ross Sea (Antarctica)
}

\author{
S. Fonda Umani ${ }^{\text {a, * }}$, M. Monti ${ }^{\text {a }}$, C. Nuccio ${ }^{b}$ \\ ${ }^{a}$ Laboratory of Marine Biology, Via Piccard 54, 34010 Trieste, Italy \\ ${ }^{\mathrm{b}}$ Department of Plant Biology, Via Micheli 1, 50121 Firenze, Italy
}

Received 15 October 1995; accepted 15 August 1997

\begin{abstract}
This work describes the spatial and vertical distribution of microzooplankton (20-200 $\mu \mathrm{m})$ abundance and biomass of the upper layers $(0-100 \mathrm{~m})$, collected during the first oceanographic Italian expedition in Antarctica $(1987 / 1988)$ in Terra Nova Bay (Ross Sea). Biomass was estimated by using biovolume calculations and literature conversion factors. Sampling was carried out at three depths, surface, 50 and $100 \mathrm{~m}$. The dominant taxa were made up of tintinnid ciliates, ciliates other than tintinnids, larvae of micrometazoa and heterotrophic dinoflagellates. The abundance of the total microplankton fraction had its absolute maximum in the center of Terra Nova Bay at the surface with 31042 ind. $\mathrm{dm}^{-3}$. The areal and vertical distribution of heterotrophic microplankton biomass differs from that of abundance. On the basis of hydrological conditions, phytoplankton composition and biomass and microzooplankton biomass and structure it is possible to identify three groups of stations: 1 -northern coastal stations (intermediate chlorophyll maxima, microphytoplankton prevalence, low microzooplankton biomass); 2-central stations (high surface chlorophyll, nanoplankton prevalence, high abundance of microzooplankton); 3 -northern stations (deeper pycnocline, nanoplankton prevalence, high microzooplankton biomass at intermediate depths).
\end{abstract}

\section{Résumé}

L'objet de cette étude a étail la distribution spatiale et verticale de l'abondance et de la biomasse du microzooplancton échantillonné pendant la première expédition antarctique italienne (1987/1988) a Terra Nova Bay (Ross Sea). Les échantillons ont été prélevés à trois différentes profondeurs: surface, 50 et $100 \mathrm{~m}$. Les taxa dominantes ont été les tintinnides ciliés, les ciliés autre que les tintinnides, les larves de micrometazoaire et les dinoflagelles hétérotrophes. La valeur maximale (31042 ind. $\mathrm{dm}^{-3}$ ) d'abondance du microzooplancton total a été mesurée dans le niveau de surface de la zone centrale. La distribution spatiale et verticale de la biomasse du microzooplancton hétérotrophe est différente de celle de l'abondance. Trois groupes de stations ont été mis en évidence sur la base des conditions hydrologiques, de la composition et la biomasse du phytoplancton et la structure et la biomasse du microzooplancton: 1-stations côtières du nord (valeur maximal de chlorophylle dans les niveau intermédiaires, majorité de microphytolancton et faible biomasse du microzoo-

\footnotetext{
* Corresponding author. Tel.: +39-40-224400; Fax: +39-40-224437; E-mail: labbioma@univ.trieste.it 
plancton); 2-stations centrales (haute valeur de chlorophylle de surface, majorité de nanoplancton et forte abondance de microzooplancton); 3-stations du nord (pycnocline plus profonde, majorité de nanoplancton, hautes valeurs de biomasse du microzooplancton dans les niveau intermédiaires). (c) 1998 Elsevier Science B.V. All rights reserved.

Keywords: microzooplankton; Terra Nova Bay; tintinnid ciliates

\section{Introduction}

The role of heterotrophic microzooplankton in the interpretation of the biological processes occurring in the Southern Ocean increased in the last decade due to the discovery of its importance as a key link in the transfer of newly formed organic matter by nano and picoplankton to mesozooplankton (Gifford, 1988; Alder and Boltovskoy, 1991; Burkill et al., 1993, 1995).

Pico- and nanoplanktonic producers often dominate the post-bloom successional stages of Antarctic phytoplankton accounting for up to $80-90 \%$ of total autotrophic production (Alder and Boltovskoy, 1993; Garrison et al., 1993). Microplanktonic heterotrophs, which almost alone are able to feed on nanoplankton and repackage the organic material into a size suitable for consumption at higher levels of the food web, can sustain in large part the high standing stock of Antarctic crustaceans. Among the heterotrophic microplankters, ciliates (including tintinnids), microcrustacea and various invertebrate larvae are all relevant in terms of biomass. Heterotrophic dinoflagellates also contribute significantly to the microheterotrophic biomass (Dodge and Priddle, 1987; Bjørnsen and Kuparinen, 1991; Elbrächter and Zölfel, 1993) sometimes accounting for more than $50 \%$ of the total heterotrophic biomass (Alder and Boltovskoy, 1993), and more than $60 \%$ in the $0-150$ $m$ depth range (Boltovskoy and Alder, 1992). Their distribution is affected by high heterogeneity, with patches of relatively high abundance related to some particular current pattern (Dodge and Priddle, 1987). The purpose of this work is to present the areal and vertical distributions (in the upper $100 \mathrm{~m}$ ) of heterotrophic biomass in Terra Nova Bay (Ross Sea) during an austral summer $(1987 / 1988)$ and their relationship with the water column structure and chlorophyll $a$ distribution.

\section{Materials and methods}

During the $1987 / 1988$ cruise hydrological profiles were performed at each station by means of a Meerestechnik Mod. KMS multiparametric (CTD) probe with a frequency of 8 readings /s (Boldrin and Stocchino, 1990).

Downwelling PAR irradiance and downwelling, upwelling and scalar underwater irradiance were

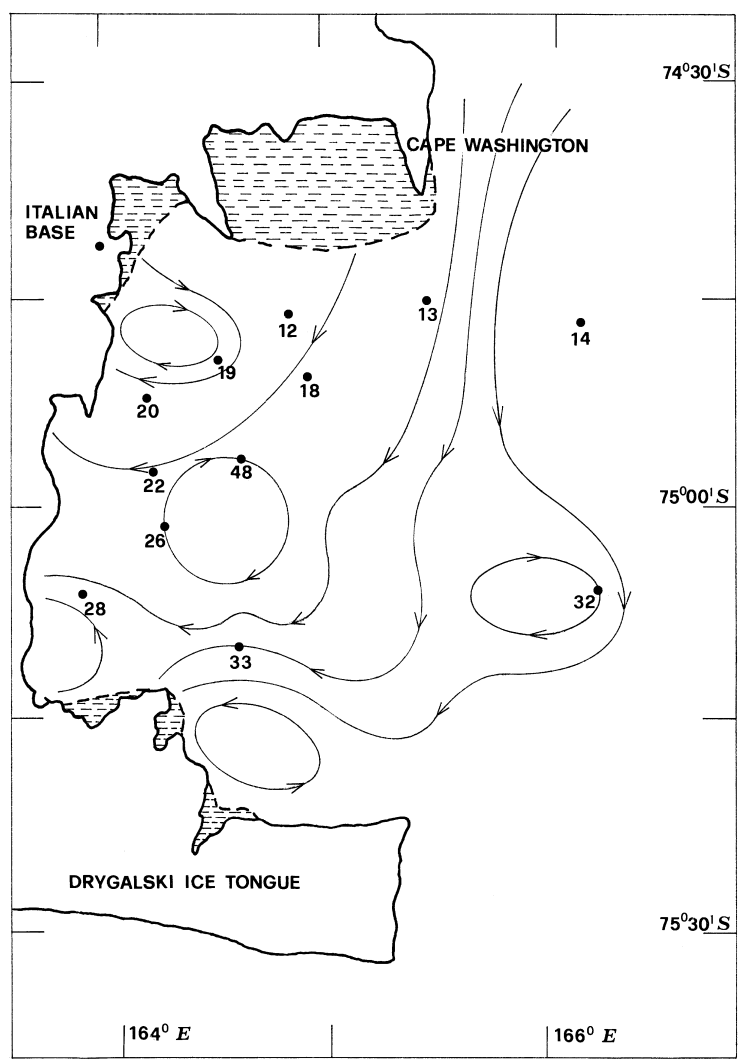

Fig. 1. Study area and sampling stations with the most important currents (redrawn from Stocchino and Manzella, 1991). 
measured by means of LI-COR quantum sensor (Innamorati et al., 1990). Chlorophyll $a$ concentrations were determined spectrophotometrically or fluorometrically, after extraction in $90 \%$ acetone (Innamorati et al., 1990).

From 9 January 1988 to 2 February 1988 water samples for microzooplankton analyses were obtained with sampling bottles at 3 depths (surface, 50 $\mathrm{m}$, and $100 \mathrm{~m}$ ) at 12 stations in Terra Nova Bay (Fig. 1). At each station water samples were simultaneously collected at the same depths for chlorophyll $a$ concentration and nano-and micro-phytoplankton analyses. Sampling times varied between $10 \mathrm{AM}$ and 8 PM. Each station was occupied once; stations 20, 19, 22, 26, 28 and 33 were sampled between 9 and 15 January; stations 12, 13, 14, 18, 48 and 32 between 24 January and 2 February. The farthest stations from the coast were stations 32 (42 miles) and 14 (33 miles); all other stations were within 15 miles from the coast.

For each sample, 21 of water were collected, concentrated on $20 \mu \mathrm{m}$ mesh, and reduced to $250 \mathrm{cc}$. For dinoflagellate counting, unfiltered water was used. Samples were preserved with $4 \%$ formaldehyde solution buffered with sodium tetraborate. Subsamples (50-100 ml) were then examined in a settling chamber using an inverted microscope (magnitude $\times 200$ and $\times 320$ ), according to the method of Utermöhl (1958).

The biomass of microzooplankton organisms was estimated by measuring the linear dimension and equating shapes to standard geometric figures or combinations of them. Measurements were taken for each species (or groups of eggs, larvae, etc.) on more than 100 individuals (max. 394 for Cymatocylis drygalskii) for the abundant taxa and on the few present individuals for rare taxa. Conversion factors used to transform these volumes into organic carbon values were, dinoflagellates: pg $\mathrm{C}=\mu \mathrm{m}^{3} \times 0.13$ (Edler, 1979); tintinnids: pg $\mathrm{C}=\mu \mathrm{m}^{3} \times 0.053+444.5$ (Verity and Langdon, 1984); ciliates other than tintinnids: pg $\mathrm{C}=\mu \mathrm{m}^{3} \times 0.14$ (Putt and Stoecker, 1989); all other groups: pg $\mathrm{C}=\mu \mathrm{m}^{3} \times 0.08$ (Beers and Stewart, 1970).

The dinoflagellates included in our computation were all species belonging to the Protoperidinium genus (Dodge and Priddle, 1987; Elbrächter and Zölfel, 1993) or Gyrodinium lachryma (Lessard and
Swift, 1986) and Gymnodinium sp. (Bjørnsen and Kuparinen, 1991).

The microzooplankton composition at each station and at the three depths was organized in a matrix of 34 rows (taxa) and 36 columns (stations depths).

Cluster analysis, based on the complete linkage method, was computed by MATEDIT (Burba et al., 1992) on the matrix after calculating the correlation coefficient on species and the similarity ratio on stations' depths.

\section{Results}

\subsection{Hydrology}

The study area in Terra Nova Bay extended approximately between $74^{\circ} 30^{\prime}$ and $75^{\circ} 30^{\prime} \mathrm{S}$ and $164^{\circ} 00^{\prime}$ and $166^{\circ} 00^{\prime} \mathrm{E}$ (Fig. 1). The maximum depth ( $>1100$ $\mathrm{m})$ is in the central part of the Bay bordered by a high and rocky coast and characterized by an extremely steeply sloping sea-floor (Brambati et al., 1989). The hydrology of the study area, during the summer period is characterized by the presence of a stable pycnocline and high temperature and salinity gradients. The thick surface layer of Antarctic Surface Water (AASW) has temperatures exceeding $0^{\circ} \mathrm{C}$. In the coastal areas the surface layer is characterized by a salinity of $>34.7$ psu and temperatures between $1.9^{\circ} \mathrm{C}$ to $2.1^{\circ} \mathrm{C}$. This area is affected by prevailing surface thermal processes due to both atmospheric and orographic phenomena which can maintain the polynya over winter. Eastward, the offshore surface water is affected by dilution processes due to meteoric ice melting. Consequently, the salinity is $<34.6$ psu. Below the AASW a homogeneous water body of Ross Sea Shelf Water (RSSW) is present. Here the salinity increases slightly towards the bottom with an average temperature of $-1.9^{\circ} \mathrm{C}$ and salinity of 34.9 psu (Boldrin and Stocchino, 1990).

During the $1987 / 1988$ cruise pycnocline deepened from $50-75 \mathrm{~m}$ depth of the first sampled coastal stations $(19,20,22,26,28$ and 33) to $100 \mathrm{~m}$ depth of the last northern stations (12, 13, 14 and 18); the easternmost station 32 and central station 48 , sampled during the second period, still showed pycnocline at 50-75 $\mathrm{m}$ depth (Fig. 2); the latter was 

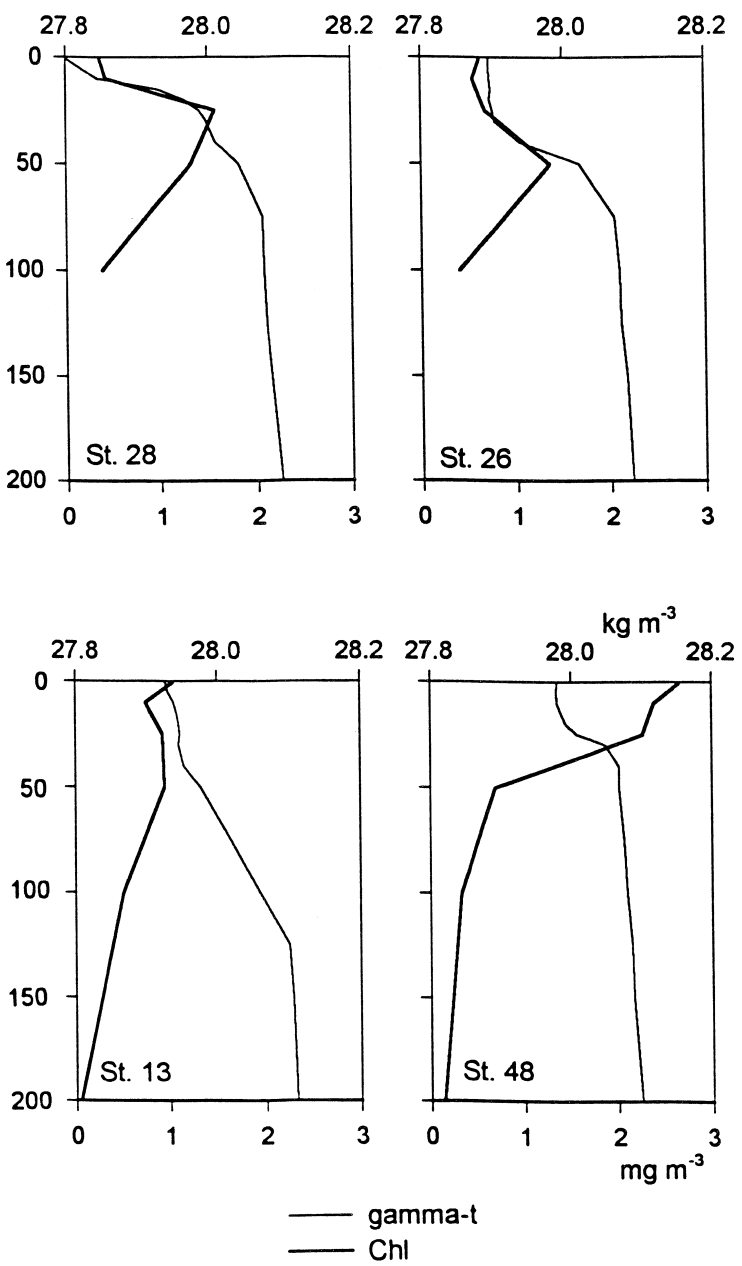

Fig. 2. Density and chlorophyll $a$ typical profiles of the three main group of stations: stations 28 and 26 show profiles of coastal stations $(19,20,22,26,28$ and 33); station 13 shows profile of northern stations $(12,13,14$ and 18); station 48 shows profile of central stations 48 and 32 .

characterized by the lowest temperatures (from $-0.6^{\circ} \mathrm{C}$ at surface to $-2.0^{\circ} \mathrm{C}$ at $300 \mathrm{~m}$ depth). At all other stations surface temperature was $>0.6^{\circ} \mathrm{C}$, with maxima at the most southern stations 28 and 33 $\left(>1.6^{\circ} \mathrm{C}\right)$. Only at station 20 surface temperature was $<0^{\circ} \mathrm{C}$. At the surface the lowest salinity was found at the easternmost stations 14 and $32(<34.6$ psu); while at all other stations it was $>34.75$ (Boldrin and Stocchino, 1990).

The surface currents are constituted by two branches (Fig. 1): the first originates from the NE in the northernmost part of the Bay and the second from the $\mathrm{E}$ in the southernmost region south of $75^{\circ} \mathrm{S}$. The NE current invades the central area and then turns $\mathrm{N}$ to become the coastal current. The second one, from the E, after reaching the Drygalski Ice Tongue, turns $\mathrm{N}$ to join the coastal current. Generally the surface circulation is characterized by a stable cyclonic gyre (Stocchino and Manzella, 1991).

\subsection{Chlorophyll $a$ and phytoplankton distribution}

Absolute surface chlorophyll maxima ( $>2.3 \mathrm{mg}$ $\mathrm{m}^{-3}$ ) were recorded at stations 32 and 48; at stations 12, 13, 14 and 18 less intense $\left(<1.3 \mathrm{mg} \mathrm{m}^{-3}\right)$ surface or subsurface maxima were registered (Fig. 3). At all other stations, the chlorophyll maximum occurred at depths ranging from 25 to $50 \mathrm{~m}$, corresponding to the different water mass structures (Fig. 2). At stations 32 and 48 the euphotic layer depth $\left(Z_{\text {eu }}\right)$ was particularly thin; where $1 \%$ of surface PAR recorded at 21 and $22 \mathrm{~m}$ depths, respectively. $Z_{\text {eu }}$ was maximum at station $14(43 \mathrm{~m})$. Integrated over $100 \mathrm{~m}$ depth chlorophyll (Fig. 4) was higher in the coastal northern area, followed by the central part of the grid.

Phytoplankton abundance (Fig. 5) was maximum at station 48 ( $25 \mathrm{~m}$ depth), reaching $963 \times 10^{3}$ cell $1^{-1}$; at this depth $90.77 \%$ of total phytoplankton was constituted by nanoplankton. This station was the richest also at surface and $10 \mathrm{~m}$ depth, and still nanoplankton was the dominant fraction, as well as at stations 14, 18, 20, 32 and in the upper layers of 12 and 13. Microphytoplankton prevailed at stations 19, 22, 26, 28 and 33; nanoplankton generally increased below $50 \mathrm{~m}$ depth. Total phytoplankton abundance at these stations ranged between $2 \times 10^{3}$ and $166 \times 10^{3}$ cell $1^{-1}$. Generally, the highest total abundances of phytoplankton corresponded to the highest percentages of nanoplankton.

\subsection{Microzooplankton abundance and biomass}

Abundance of the total microplankton fraction (including dinoflagellates, tintinnids, aloricate ciliates, larvae and eggs of invertebrates) is maximum (Fig. 6) at station 48 at the surface (31042 ind. $\mathrm{dm}^{-3}$ ), due to the conspicuous contribution of Pro- 


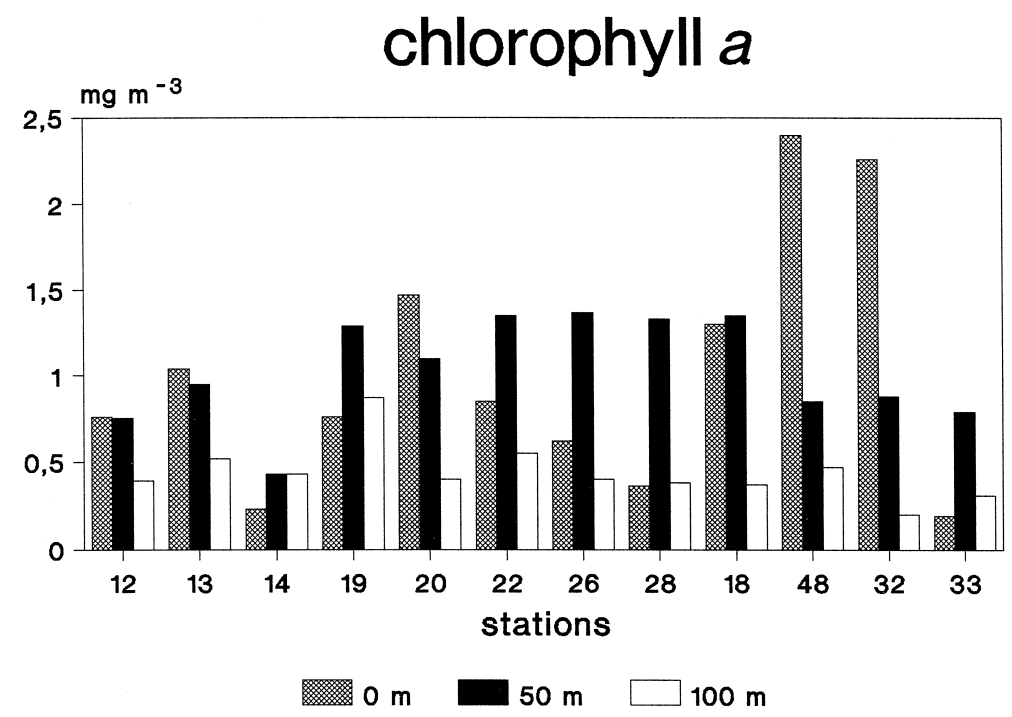

Fig. 3. Chlorophyll $a$ values $\left(\mathrm{mg} \mathrm{m}^{-3}\right)$ at surface, 50 and $100 \mathrm{~m}$.

toperidinium defectum, P. mediocre and Gymnodinium sp. At the surface at all other stations, values are lower and variable. The contribution by dinoflagellates is considerable everywhere. At intermediate depths numbers were more uniform than in surface waters and dinoflagellate contribution to the total abundance was of the same order as at the surface

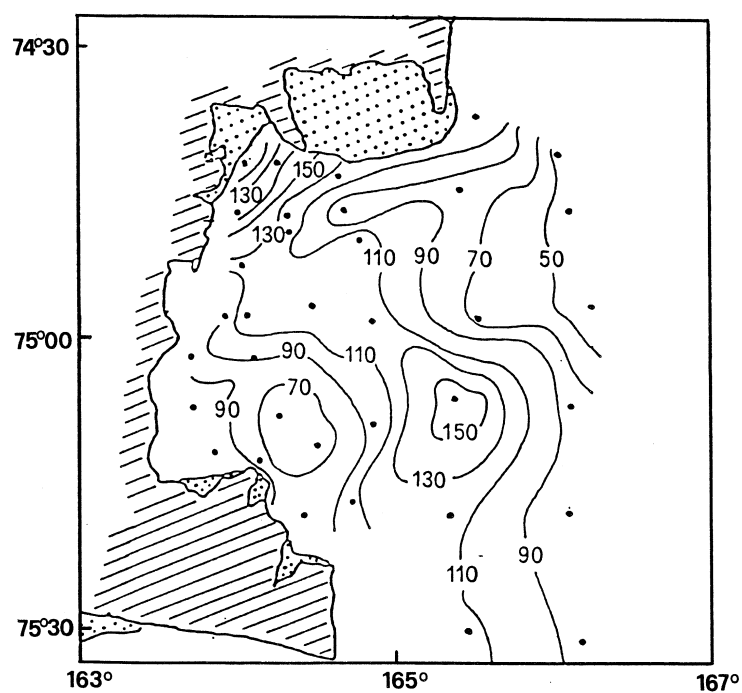

Fig. 4. Contour map of integrated over $100 \mathrm{~m}$ depth chlorophyll $a$ (from Innamorati et al., 1992).
(Fig. 7a and b). At $100 \mathrm{~m}$, the maximum, although less than 20000 ind. $\mathrm{dm}^{-3}$, appears at station 13; at all other stations values are low, particularly when dinoflagellates are absent (Fig. 7c).

In Table 1, where individual biovolume and carbon content calculated for each organism is reported, it is noticeable that the biomass values of some dinoflagellates, in particular Protoperidinium antarcticum and $P$. pseudoantarcticum, are in the same range as tintinnid carbon values. The other dinoflagellates are 10-20 times less abundant in terms of carbon biomass.

The spatial and vertical distribution of heterotrophic microplankton biomass shows a quite different pattern from that of abundance (Fig. 8). At the surface, the richest station was 13 , while at station 48 , biomass is relatively high but of the same order of magnitude as at all other stations. At intermediate depths, stations 13 and 14 exhibited biomass maxima more than 4 times higher than at all other stations. Only at $100 \mathrm{~m}$ depth at stations 14 and 13 was there a good correspondence between abundance and biomass distribution.

The high values at stations 13 and 14 are due to the conspicuous presence of dinoflagellates (Fig. 9), which account for more than $97 \%$ of the total (station $14 ; 100 \mathrm{~m}$ ). At these stations, a bloom of the very large $P$. antarcticum, whose carbon content is 


\section{Phytoplankton abundance surface}

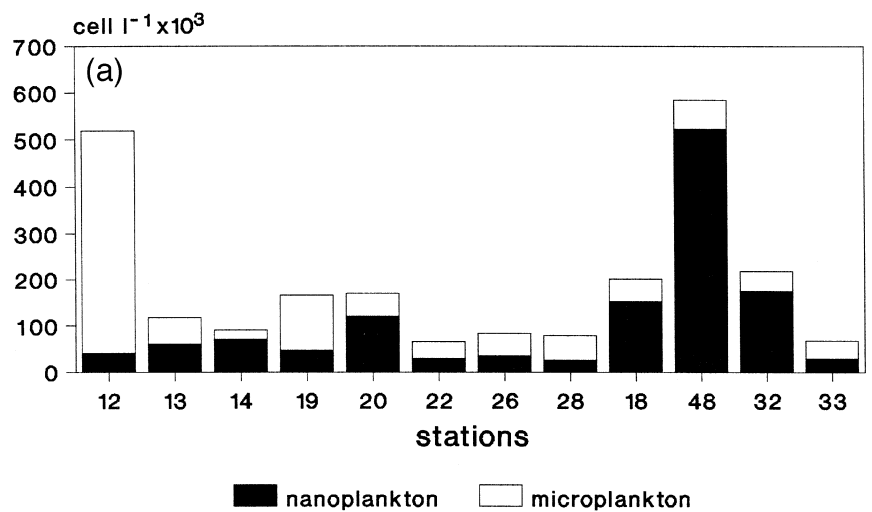

$50 \mathrm{~m}$

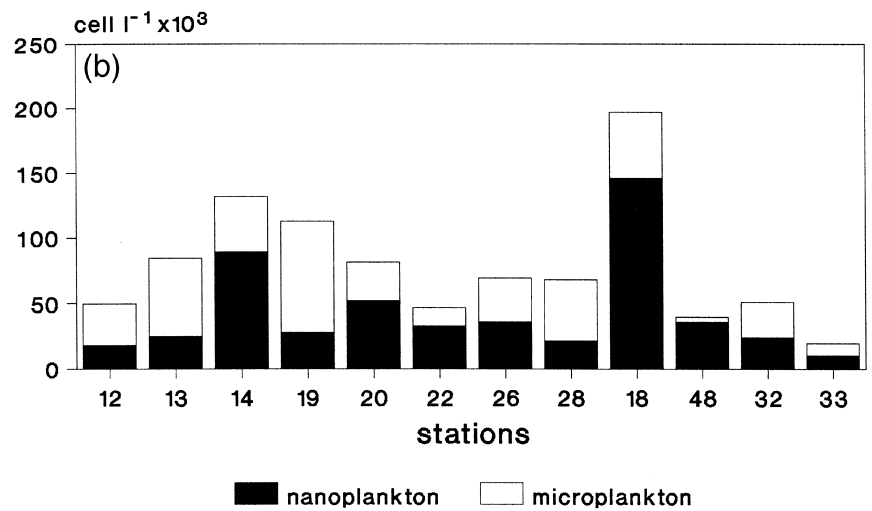

$100 \mathrm{~m}$

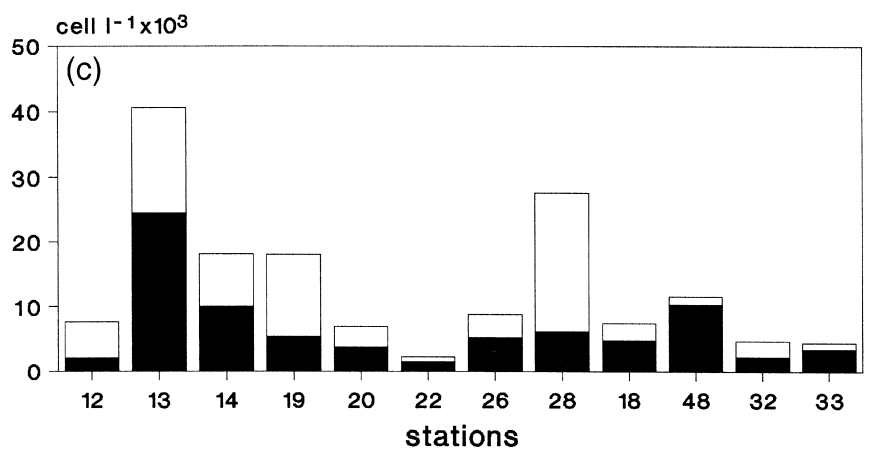

nanoplankton $\square$ microplankton 


\section{Microzooplankton abundance}

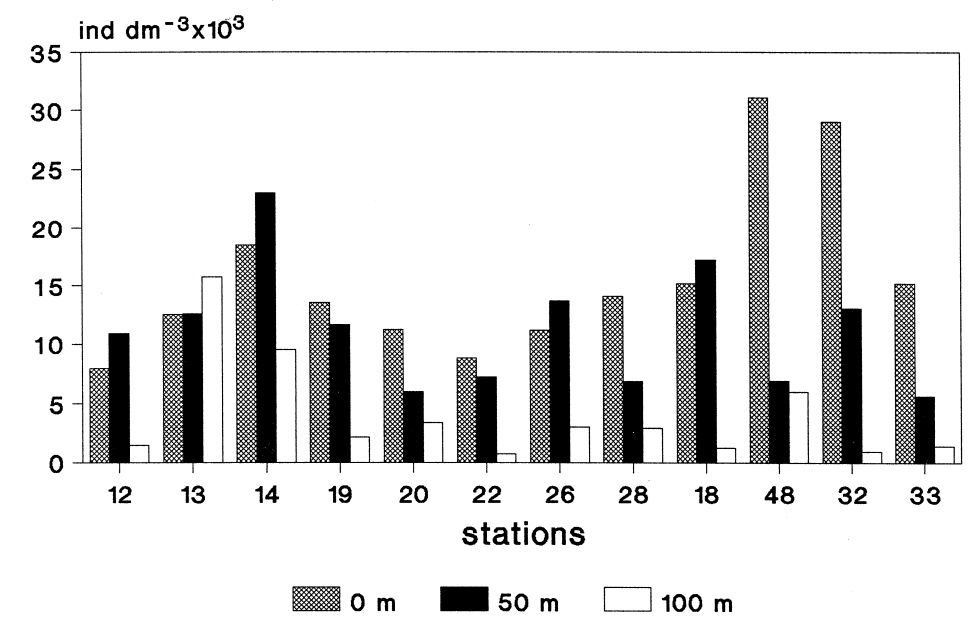

Fig. 6. Total microzooplankton abundance (ind. $\mathrm{dm}^{-3}$ ) at surface, 50 and $100 \mathrm{~m}$ depth.

60930 pg C (Table 1), was particularly developed at $50 \mathrm{~m}$ depth.

At all other stations the contribution of dinoflagellates to the total biomass is generally higher at the surface. The differences observed between abundance and biomass distribution are mainly due to the different composition of the heterotrophic dinoflagellate community at the various stations: e.g., at station 48 (surface) $P$. defectum and P. mediocre dominated, characterized by a small biovolume and consequently low carbon content (Table 1).

The contribution to the total biomass of ciliates other than tintinnids is again more important at the surface with a maximum of $26 \%$ at station 22 and generally it is more than $10 \%$.

Tintinnids show generally the highest percentage at intermediate and bottom layers with a maximum of $82 \%$ at station 22 at $100 \mathrm{~m}$.

The biomass of eggs and larval forms of invertebrates, among which the contribution of copepod nauplii is not very significant, was more abundant in the northern coastal stations (12,18, 19 and 20), reaching a maximum of $31 \%$ of the total biomass at stations 19 at 50 and $100 \mathrm{~m}$.

\subsection{Community structure}

Cluster analysis defined 2 main stations' depth groups: 1 and 2 (Fig. 10); group 2 is comprised by $100 \mathrm{~m}$ samples of stations 19, 20, 22, 12, 33 and 26.

Group 1 can be divided into six subgroups: 1.1 and 1.2 identified surface samples of stations 13, 22, 12, 33, 14, 19, 28 and $50 \mathrm{~m}$ samples of station 19. Group 1.3 included surface samples of stations 18 , 26 and 32 and $100 \mathrm{~m}$ samples of stations 28 and 32 . Group 1.4 comprehended $50 \mathrm{~m}$ samples of stations $18,28,26,32,22,33$ and 12; group 1.5 samples at 50 and $100 \mathrm{~m}$ depths of stations 13 and 14. In group 1.6 are included all the depths of station 48 , surface and $50 \mathrm{~m}$ of station 20 and the $100 \mathrm{~m}$ sample of station 18.

Cluster analysis applied on species identified six groups of species (Fig. 11): only group C is more or less homogeneously distributed in all the stations' depth groups (Table 2), being constituted primarily

Fig. 5. Phytoplankton abundance at surface (a), $50 \mathrm{~m} \mathrm{(b)}$ and $100 \mathrm{~m}$ depth (c). Bars division show nanoplankton and microphytoplankton relative contribution to the total abundance. 


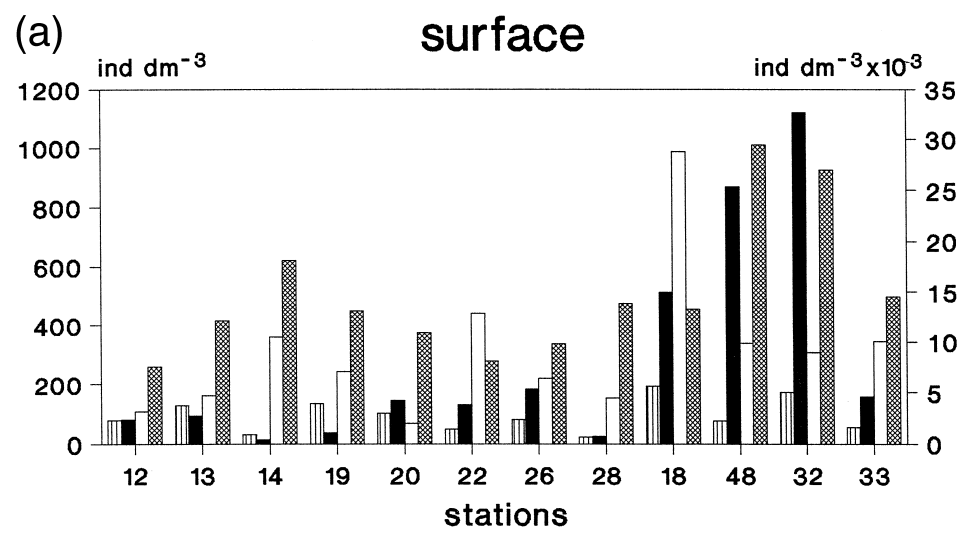

血血larvae $\square$ tintin. $\square$ ciliates $\quad$ dinofl.

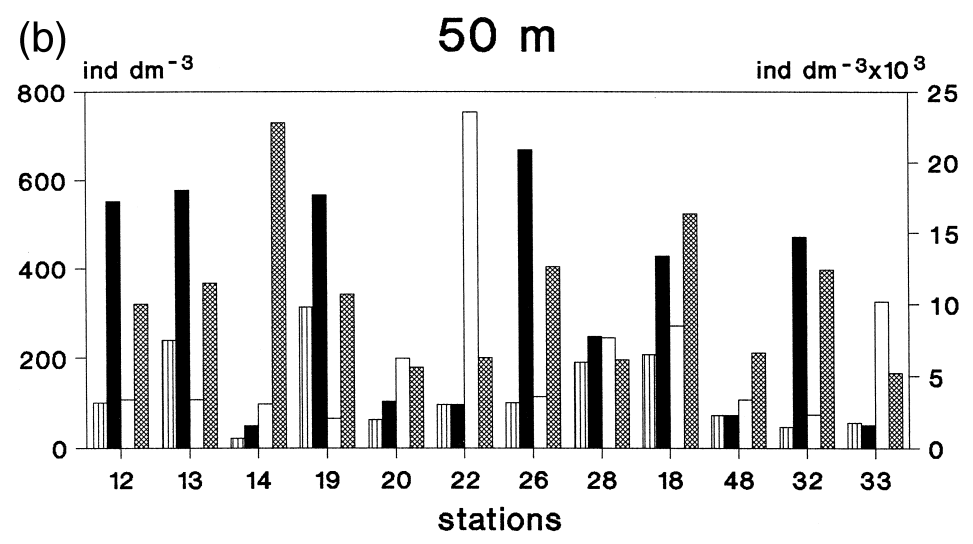

而血 larvae $\square$ tintin. $\square$ ciliates $\quad$ dinofl.

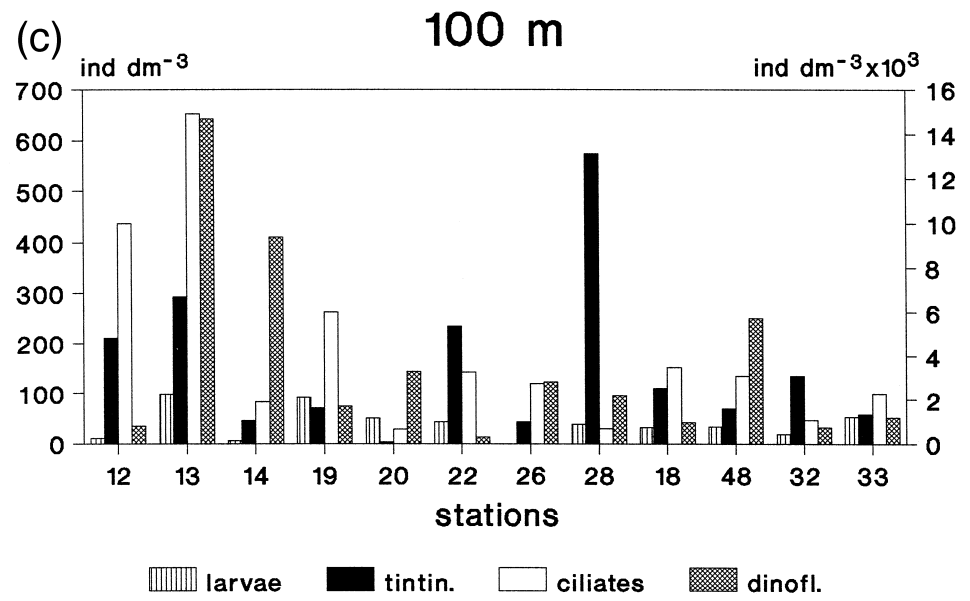

Fig. 7. Microzooplankton abundance (ind. $\mathrm{dm}^{-3}$ ) of dinoflagellates, tintinnids, ciliates and larvae and eggs, at surface (a), $50 \mathrm{~m}$ (b) and 100 $\mathrm{m}$ (c). Second scale is used to show dinoflagellate abundances. 
Table 1

Individual biovolume and carbon content

\begin{tabular}{|c|c|c|}
\hline & $\mu \mathrm{m}^{3}$ & pg C \\
\hline \multicolumn{3}{|l|}{ Dinoflagellates } \\
\hline Gymnodinium sp. & 4320 & 561 \\
\hline Gyrodinium lachryma & 3470 & 4520 \\
\hline Protoperidinium adeliense & 7600 & 990 \\
\hline P. antarcticum & 468700 & 60930 \\
\hline P. applanatum & 11970 & 1560 \\
\hline P. defectum & 6790 & 880 \\
\hline P. pseudoantarcticum & 278220 & 36170 \\
\hline P. mediocre & 14930 & 1940 \\
\hline P. unipes & 24870 & 3230 \\
\hline \multicolumn{3}{|l|}{ Tintinnids } \\
\hline Cymatocylis drygalskii & 467440 & 25220 \\
\hline C. flava & 800220 & 42860 \\
\hline Cymatocylis sp. & 513980 & 27680 \\
\hline Laackmanniella naviculaefera & 384200 & 20810 \\
\hline L. prolongata & 312870 & 17030 \\
\hline Laackmanniella sp. & 247100 & 13540 \\
\hline Codonellopsis gaussi & 98770 & 5680 \\
\hline C. glacialis & 57270 & 3480 \\
\hline Codonellopsis sp. & 116000 & 6590 \\
\hline Salpingella sp. & 251200 & 13760 \\
\hline Coxliella frigida & 72350 & 4280 \\
\hline Ptychocylis sp. & 108090 & 57730 \\
\hline \multicolumn{3}{|l|}{ Ciliates } \\
\hline Ciliates A & 36250 & 5070 \\
\hline Enchelys sp. & 61790 & 8650 \\
\hline Prorodon sp. & 101900 & 14260 \\
\hline Lacrymaria sp. & 9650 & 1350 \\
\hline Halteria sp. & 127510 & 17850 \\
\hline Strombidium sp. & 21040 & 2940 \\
\hline Patronella sp. & 100970 & 14140 \\
\hline Leegardiella sp. & 27450 & 3840 \\
\hline Lohmaniella sp. & 25960 & 3630 \\
\hline Oligotricha sp. & 84780 & 11870 \\
\hline \multicolumn{3}{|l|}{ Larvae and eggs } \\
\hline Nauplii & 367500 & 29400 \\
\hline Limacina veliger & 569890 & 45590 \\
\hline Larvae unid. & 145680 & 11650 \\
\hline Eggs unid. & 112530 & 9000 \\
\hline
\end{tabular}

by Cymatocylis sp. and rare species such as Sticholonche zanclea and Laackmaniella naviculifaera.

Group A was constituted by heterotrophic dinoflagellates, is typical of 50 and $100 \mathrm{~m}$ depths of northern offshore stations (13 and 14).

Groups B and D species characterized the intermediate depths of group 1.4 (above). In group B, $P$. defectum and Laackmaniella prolongata prevailed, in group D, Lohmaniella sp., Leegardiella sp. and unidenfied ciliates as well as Cymatocylis flava prevailed.

Group E species in which Cymatocylis drigalskii prevailed, characterized the upper layer of the coastal stations (group 1.1).

Group F species of which the most abundant is Codonellopsis gaussi characterized the upper layers at stations 18, 26 and 28 and the $100 \mathrm{~m}$ depth of stations 28 and 32.

Samples from coastal stations at $100 \mathrm{~m}$ depth of (group 1.6) were characterized by the absence or scarcity of all groups of species.

\section{Discussion and conclusion}

On the basis of the water column structure it is possible to identify 3 main groups of stations: Group 1: coastal stations 19, 20, 22, 26, 28 and 33, sampled at the end of microphytoplankton bloom, with a pycnocline located between 50 and $75 \mathrm{~m}$ depths, maxima of chlorophyll located just above the pycnocline and intermediate values of $Z_{\text {eu }}$; Group 2: stations 32 and 48, sampled during the second part of the cruise, with a pycnocline still between 50 and 75 $m$ depths, high chlorophyll maximum at surface and the shallowest euphotic layer; Group 3: northern stations 12, 13, 14 and 18, sampled during the second part of the cruise at the beginning of nanoplankton bloom, with a deeper pycnocline at, about $100 \mathrm{~m}$ depth, less intense surface maxima of chlorophyll and deeper $Z_{\text {eu }}$.

In group 1 total phytoplankton abundance was lower with a higher percentage of the microphytoplankton fraction in the upper layer and an increase of the nanoplankton fraction in the deeper layers, with the sole exception of station 20 which exhibited features similar to group 3 (see below).

In group 2, phytoplankton abundance was the highest with maxima in the upper layers constituted almost exclusively by nanoplankton.

In group 3, phytoplankton abundance was still high, characterized by high percentages of nanoplankton and maxima at 25-50 m depths.

Group 1 was characterized by low microzooplanktonic biomass, which was slightly higher at interme- 


\section{Heterotrophic biomass}

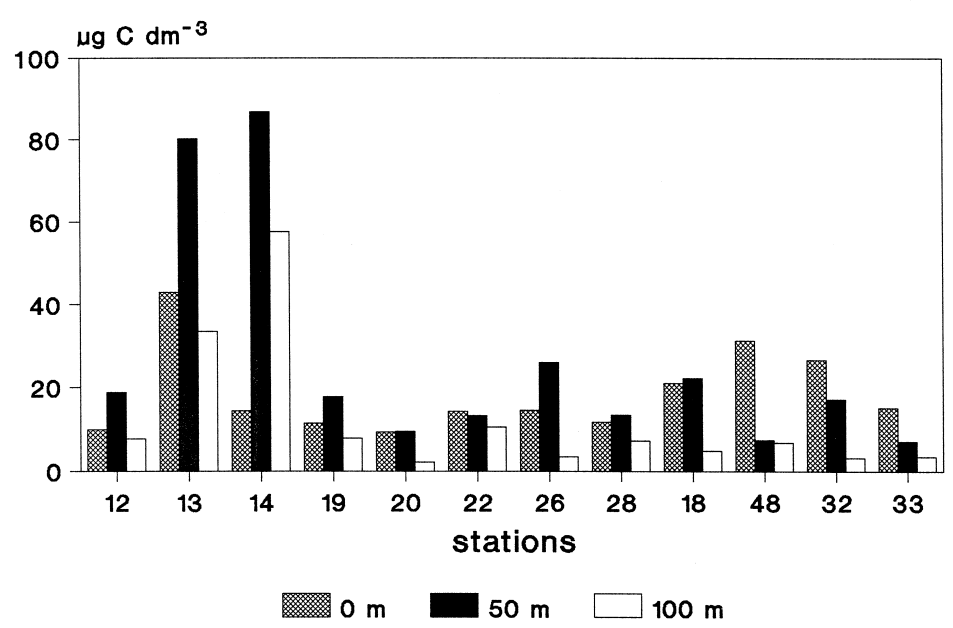

Fig. 8. Total heterotrophic biomass $\left(\mu \mathrm{g} \mathrm{C} \mathrm{dm}^{-3}\right)$ at surface, 50 and $100 \mathrm{~m}$.

diate depths. Microzooplankton abundance showed the same pattern.

Group 2 was characterized by intermediate values of heterotrophic biomass with surface maxima, mostly due to tintinnids. Here too microzooplankton abundance was the highest with surface maxima.

In group 3, two stations (13 and 14) showed a particularly high microzooplankton biomass at 50 and $100 \mathrm{~m}$ depths while all other stations belonging to this group showed high abundances at intermediate depths.

Cluster analysis clearly separated stations 13 and 14 at 50 and $100 \mathrm{~m}$ depths from the others, due to the high percentage of some species of heterotrophic dinoflagellates such as Protoperidinium antarcticum and $P$. mediocre. These stations are the most northern and offshore and they were sampled at the end of the cruise.

Stations 48 and 20 at all the depths were also separate from the others due to the prevalence of $P$. defectum at surface and to the presence of Laackmaniella spp., Pteropoda larvae and the richness of unidentified ciliates at all depths.

Surface samples of stations 18, 26 and 32 were grouped together with $100 \mathrm{~m}$ samples of stations 32 and 28 due to the dominance of Codonellospis gaussi.

For all other stations, cluster analysis generally separated the water column into three discrete layers (surface, intermediate and bottom), indicating that depth impose structure on microzooplankton communities more than other variables. This is true also for phytoplankton communities (Nuccio et al., 1992) which showed well defined structures at each layers, particularly at $50 \mathrm{~m}$ depth where a Phaeocystis bloom was recorded at all the stations of the grid.

Water mass structure changed during the cruise which covered firstly coastal stations and later offshore stations: the pycnocline deepened from the former to the latter, reaching $100 \mathrm{~m}$ depths. Chlorophyll distribution changed from maxima at intermediate depths $(25-50 \mathrm{~m})$ to surface maxima and phytoplankton composition shifted from microplankton to nanoplankton dominance. In summary, it would appear that the first leg of the cruise encountered the end of the initial phytoplankton bloom (Innamorati et al., 1992; Nuccio et al., 1992), characterized by high percentages of microplankton while the second leg encountered the onset of a secondary bloom, mostly due to nanoplankton.

The contribution of heterotrophic biomass (10$200 \mu \mathrm{m})$ appears more significant in the lower layers and in particular at $50 \mathrm{~m}$ depth, which corresponds to the pycnocline and to the base of the photic zone during the first cruise leg. This particular vertical distribution might be explained by the predator/prey relationships characteristic for microplankton con- 
(a)

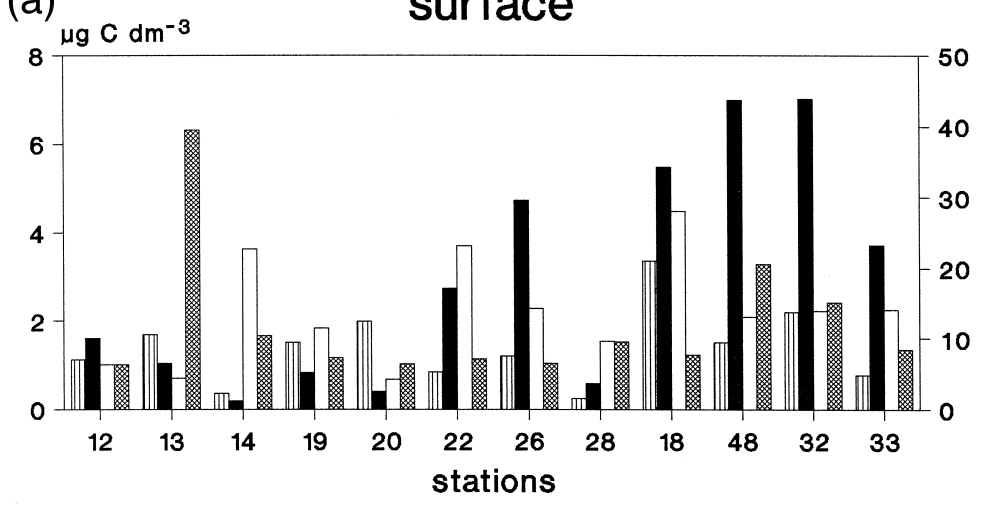

血血larvae $\square$ tintin. $\square$ ciliates dinofl.

(b) $\quad 50 \mathrm{~m}$

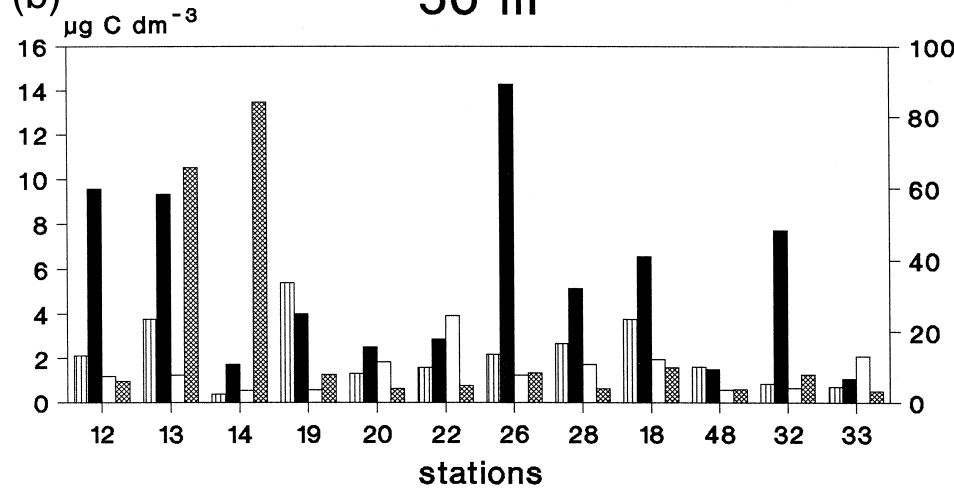

盂血 larvae $\square$ tintin. $\square$ ciliates $\quad$ dinofl.

(c) $100 \mathrm{~m}$

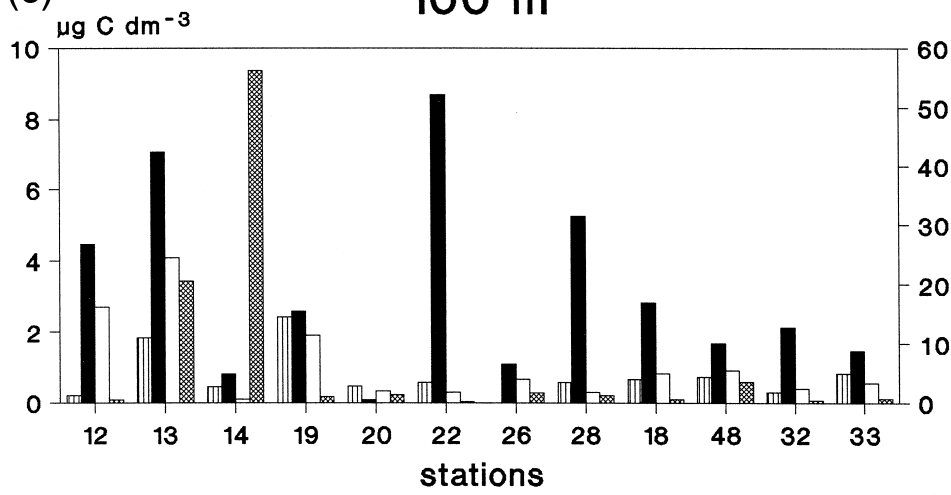

盂血 larvae $\square$ tintin. $\square$ ciliates $\quad$ dinofl.

Fig. 9. Heterotrophic biomass $\left(\mu \mathrm{g} \mathrm{C} \mathrm{dm}^{-3}\right)$ of dinoflagellates, tintinnids, ciliates, larvae and eggs, at surface (a), $50 \mathrm{~m}$ (b) and $100 \mathrm{~m}$ (c). A second scale is used to show dinoflagellate biomass. 


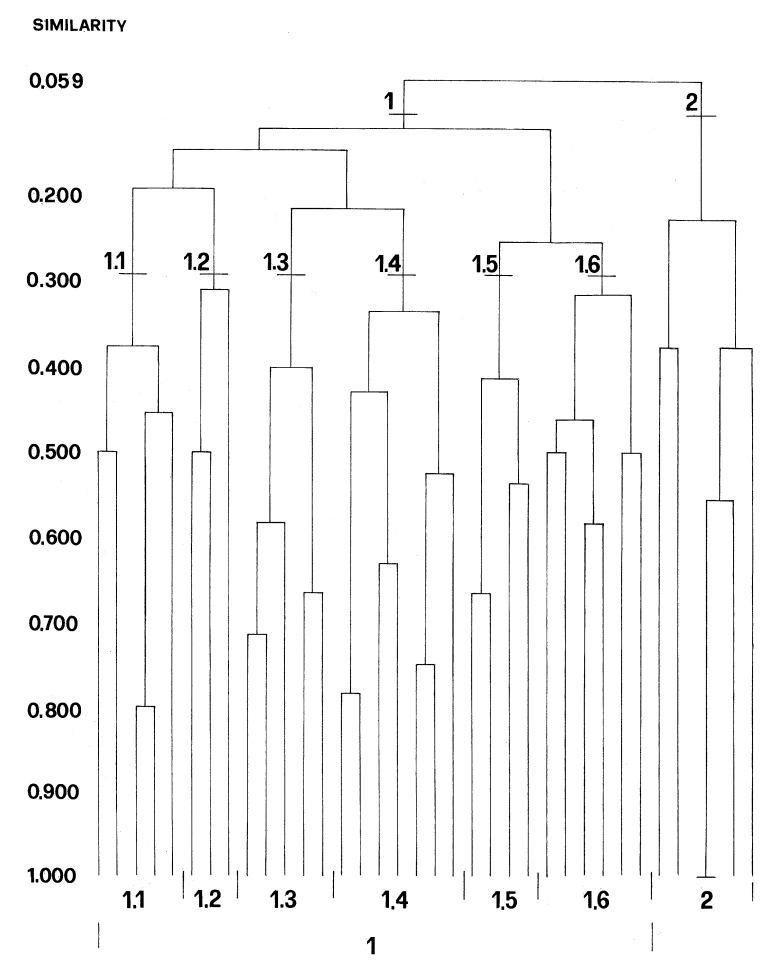

Fig. 10. Grouping of stations using the dendrogram classification obtained by processing the species / samples matrix with the similarity ratio and complete linkage method.

sumers which generally feed on particles $<20 \mu \mathrm{m}$ (Rassoulzadegan et al., 1988; Pierce and Turner, 1992). Below the $25 \%$ of irradiance depth (4.5-11 m) there was an increase in the picoplankton contribution to total primary production (Magazzù and Decembrini, 1992). The relative abundance of this fraction as well as that of nanoplankton at the base of the photic zone could be considered the most important factor influencing the vertical distribution of heterotrophic microplankter biomass even if other factors (i.e., vertical stability of the water column, lower inter specific competition, etc.) could have contributed to determining this distribution pattern.

The role of microzooplankton consumers in the Southern Ocean carbon appears less important at the surface than in aphotic layers where they utilize primarily pico- and nanoplankton producers and slow down the sinking of organic material through the production of small faecal pellets with lower settlement rates than large pellets produced by macrograzers (Longhurst, 1991).
Our values of total heterotrophic biomass appear consistently higher than those found in the WeddellScotia Confluence Area in 1988/1989 where maximum average values were less than $4 \mu \mathrm{g} \mathrm{C} \mathrm{dm}^{-3}$ at $20 \mathrm{~m}$ depth (Alder and Boltovskoy, 1993) or less than $8 \mu \mathrm{g} \mathrm{C} \mathrm{dm}^{-3}$ in the Weddell Sea in 1989 (Boltovskoy and Alder, 1992). This is probably due to the great contribution of heterotrophic dinoflagellates which were present in our samples, averaging $12.23 \pm 19.1 \mu \mathrm{g} \mathrm{C} \mathrm{dm}^{-3}$. Dinoflagellates generally show lower values: e.g., from 0.35 to $1.95 \mu \mathrm{g} \mathrm{C}$ $\mathrm{dm}^{-3}$ in the Weddell Sea in 1987 (Boltovskoy et al., 1989) and from 0.02 to $13.2 \mu \mathrm{g} \mathrm{C} \mathrm{dm}^{-3}$ in the Confluence Area (Alder and Boltovskoy, 1993). Their values of tintinnid carbon ranged respectively from 1.64 to $9.05 \mu \mathrm{g} \mathrm{C} \mathrm{dm}^{-3}$ and from 0.02 to 9.28 $\mu \mathrm{g} \mathrm{C} \mathrm{dm}^{-3}$. Again in the Weddel Sea, Buck et al. (1992) found tintinnid carbon ranging from 0.02 to $1.3 \mu \mathrm{g} \mathrm{C} \mathrm{dm}^{-3}$. Our mean value of $3.88 \pm 9.3 \mu \mathrm{g} \mathrm{C}$ $\mathrm{dm}^{-3}$ fits well in the range found in the previous cruises.

As regards areal distribution, dinoflagellates strongly influence the general pattern which exhibits

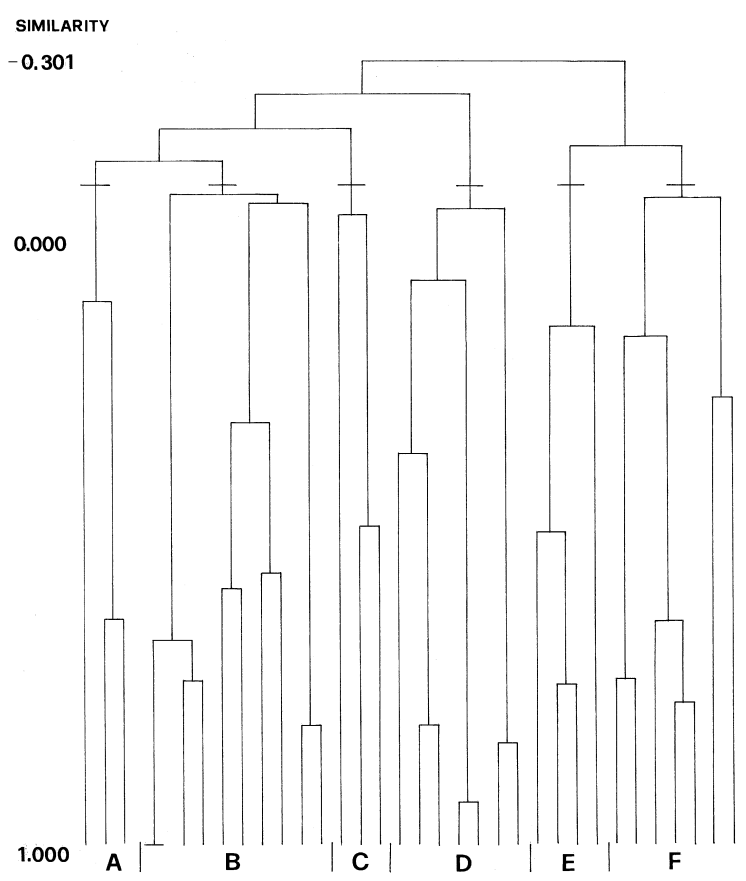

Fig. 11. Grouping of species using the dendrogram obtained by processing the species/samples matrix with the coefficient correlation and complete linkage method. 
extreme patchiness. This behaviour is often reported for heterotrophic dinoflagellates in the Southern Ocean (Dodge and Priddle, 1987; Elbrächter and Zölfel, 1993; Alder and Boltovskoy, 1993) and was thought to be associated with the flow of some particular current (Dodge and Priddle, 1987). The maximum of abundance observed at station 48 corresponds to the centre of the cyclonic gyre which establishes itself in the centre of Terra Nova Bay (Stocchino and Manzella, 1991). Another maximum is recorded at station 32 which corresponds to another gyre. At stations 48 and 32, the water mass structure is apparently similar to those of the coastal area, sampled during the first part of the cruise, but the phytoplankton community is mostly constituted of nanoplankton. Here we found the highest values of chlorophyll, of total microzooplankton abundance and of tintinnid biomass.

On the other hand the two richest stations in terms of biomass (stations 13 and 14) are the most influenced by the incoming current from the north-eastern offshore area which is evidently characterized by very large size dinoflagellate communities (namely, $P$. antarcticum and P. pseudoantarcticum).

The contribution of dinoflagellates to the total heterotrophic biomass is more important in the upper layers as is often observed (Boltovskoy and Alder, 1992; Alder and Boltovskoy, 1993). In our case,

Table 2

Reconstructed matrix following cluster analysis results

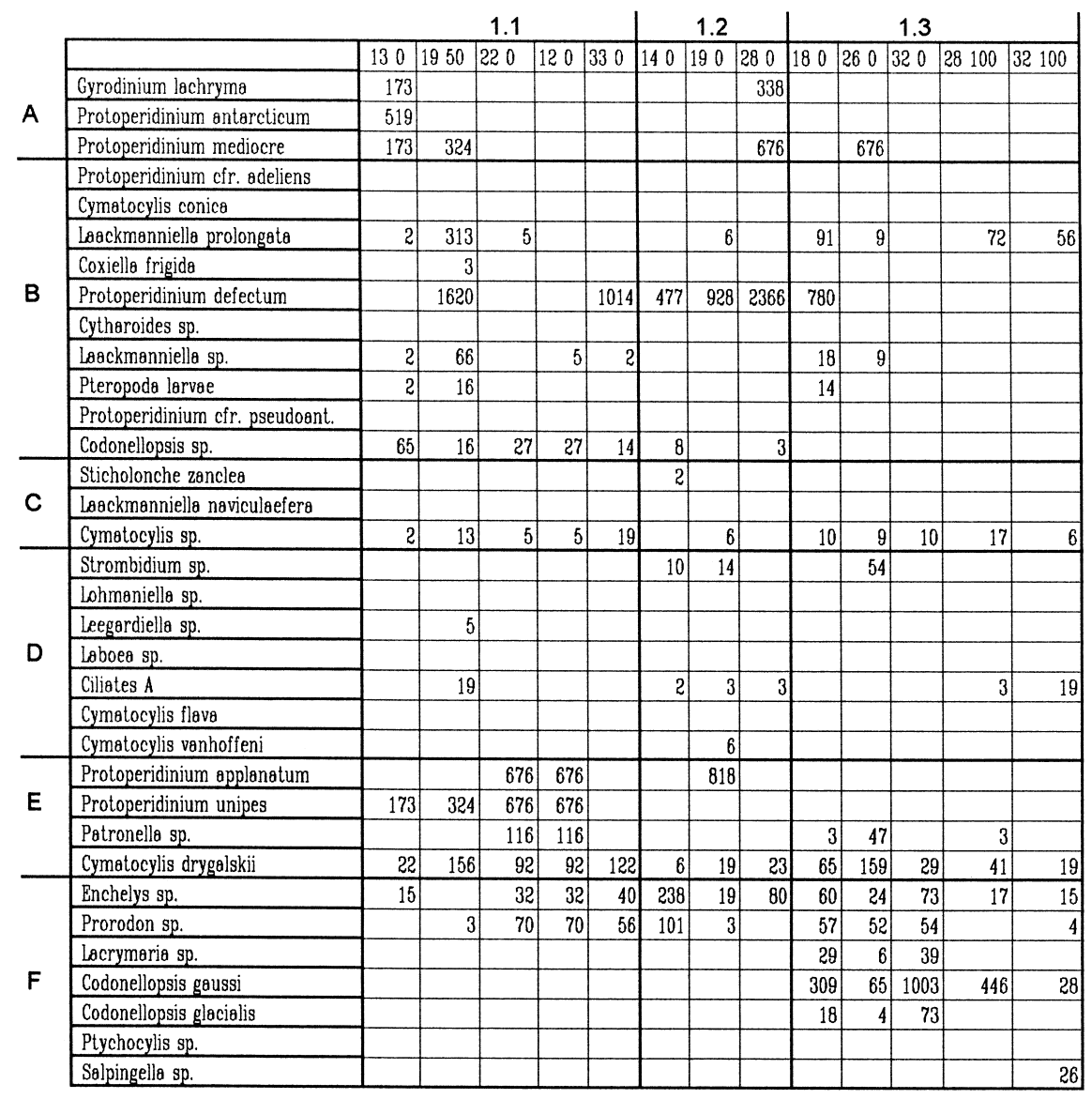


Table 2 (continued)

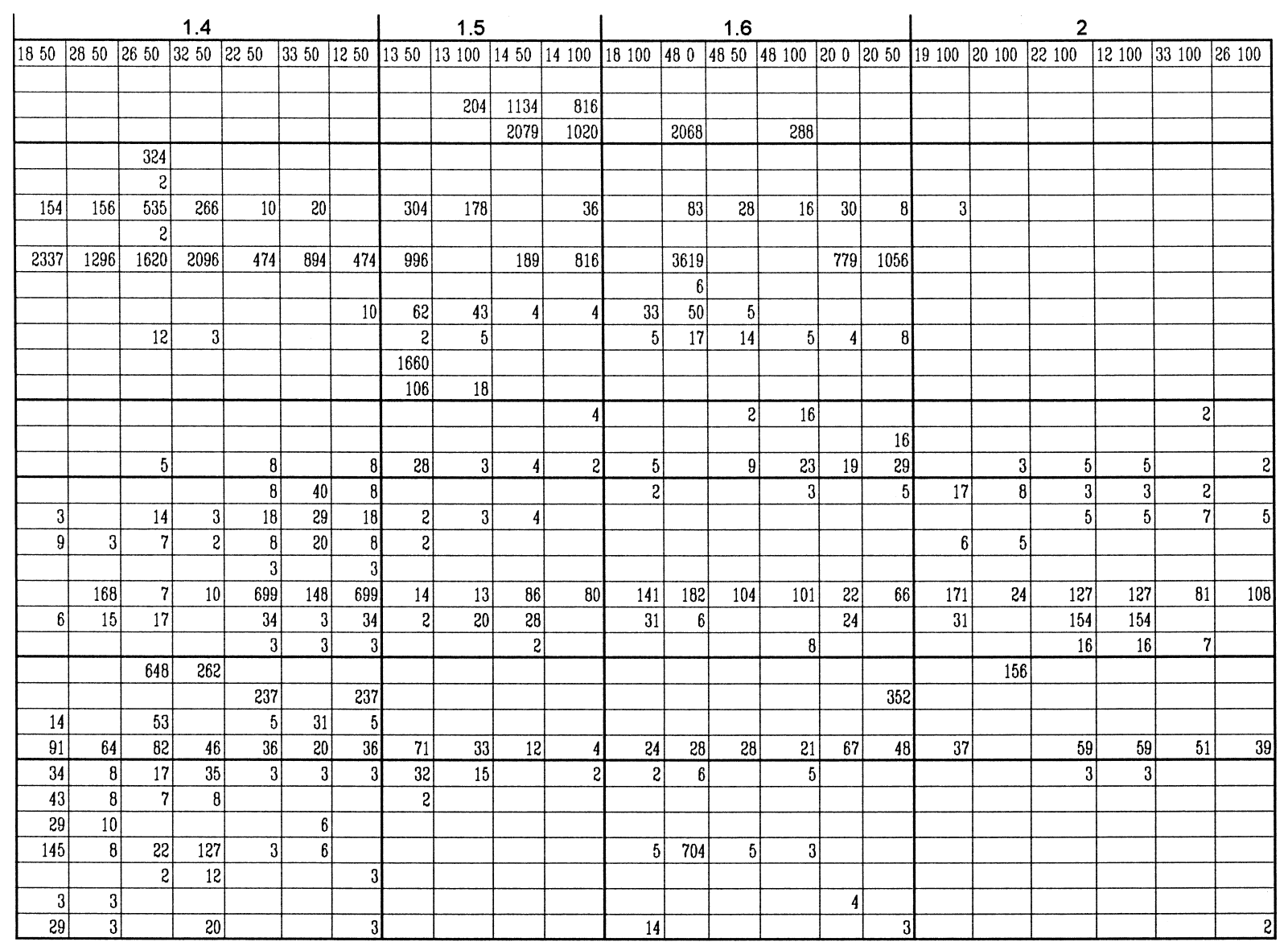

their contribution both in terms of abundance and biomass is still high also at $50 \mathrm{~m}$ depth. Again this might be explained by a higher availability of appropriate food items at this depth.

On the basis of cluster analysis, each layer was separated from the others, indicating depth to be the most influential parameter in structuring community composition.

Stations 20 and 48 appeared different from all the others, as well as stations 13 and 14 at lower depths, due to the peculiarity of their populations.

Summing up, it appears that water mass characteristics and structures, as well as timing of sampling, strongly influenced the distribution of phytoplankton biomass and composition which mostly influence the distribution of microzooplankton biomass. The microzooplankton community composition appears more related to patchiness of dominant species, which changed over the sampling time.

\section{Acknowledgements}

This work was supported by the Italian National Antarctic Research Program. Thanks are due to crew members of R/V Polar Stern and especially to Prof. Letterio Guglielmo who collected the samples during the cruise. The authors wish to thank Dr. Mike Lucas for reviewing the manuscript and for his constructive comments, and the three anonymous reviwers for suggestions and critical remarks on the manuscript. 


\section{References}

Alder, V.A., Boltovskoy, D., 1991. Microplanktonic distributional patterns west of Antarctic Peninsula, with special emphasis on the tintinnids. Polar Biol. 11, 103-112.

Alder, V.A., Boltovskoy, D., 1993. The ecology of larger microzooplankton in the Weddel-Scotia Confluence Area: horizontal and vertical distribution patterns. J. Mar. Res. 51, 323-344.

Beers, J.R., Stewart, G.L., 1970. Numerical abundance and estimated biomass of microzooplankton. In: Strickland, J. (Ed.), The Ecology of the Plankton off La Jolla, California, in the Period April through September 1967. Bull. Scripps Inst. Oceanogr. 17, 67-87.

Bjørnsen, P., Kuparinen, J., 1991. Growth and herbivory by heterotrophic dinoflagellates in the Southern Ocean, studied by microcosm experiments. Mar. Biol. 106, 1-9.

Boldrin, A., Stocchino, C., 1990. On the Hydrological characteristics of Terra Nova Bay. Nat. Sci. Com. Ant. Ocean. Camp. 1987-1988, Data Rep. 1, 11-57.

Boltovskoy, D., Alder, V.A., 1992. Microzooplankton and tintinnid species-specific assemblage structures: patterns of distribution and year-to-year variations in the Weddel Sea (Antarctica). J. Plankton Res. 14, 1405-1423.

Boltovskoy, D., Alder, V.A., Spinelli, F., 1989. Summer Weddell Sea microplankton: assemblage structure, distribution and abundance, with special emphasis on the Tintinnina. Polar Biol. 9, 447-456.

Brambati, A., Fanzutti, G.P., Finocchiaro, F., Simeoni, U., 1989. Sediments and sedimentological processes in the Ross Sea continental shelf (Antarctica): results and preliminary conclusions. Boll. Ocean. Teor. Appl. 7, 159-188.

Buck, K.R., Garrison, D.L., Hopkins, T.L., 1992. Abundance and distribution of tintinnid ciliates in an ice edge zone during the austral summer. Antarct. Sci. 4 (1), 3-8.

Burba, N., Feoli, E., Malaroda, M., Zuccarello, V., 1992. Un Sistema informativo per la Vegetazione. Sotware per l'archiviazione della vegetazione italiana e per l'elaborazione di tabelle: Manuale di utilizzo dei programmi. Quaderni CETA 2, $1-78$.

Burkill, P.H., Edwards, E.S., John, A.W.G., Sleigh, M.A., 1993. Microzooplankton and their herbivorous activity in the northeastern Atlantic Ocean. Deep Sea Res. 40, 479-494.

Burkill, P.H., Edwards, E.S., Sleigh, M.A., 1995. Microzooplankton and their role in controlling phytoplankton growth in the marginal ice zone of the Bellinghausen Sera. Deep Sea Res. 42, 1277-1290.

Dodge, J.D., Priddle, J., 1987. Species composition and ecology of dinoflagellates from the Southern Ocean near South Georgia. J. Plankton Res. 9 (4), 685-697.

Edler, L., 1979. Recommendations on methods for marine biological studies in the Baltic Sea. Phytoplankton and chlorophyll. Baltic Marine Biol. 5, 1-38.

Elbräcter, M., Zölfel, M., 1993. Taxonomy and ecology of hetero- trophic ice-flagellates. In: Spindler, M., Dieckmann, G., Thomas, D. (Eds.), The Expedition ANTARKTIS X/3 of RV Polastern in 1992. Ber. Polarforsch. 121, 26-29.

Garrison, D. L, Buck, K.R., Gowing, M.M., 1993. Winter plankton assemblage in the ice edge zone of the Weddel and Scotia Seas: composition, biomass and spatial distribution. Deep Sea Res. 40 (2), 311-338.

Gifford, D.J., 1988. Impact of grazing by microzooplankton in the Northwest Arm of Halifax Harbour, Nova Scotia. Mar. Ecol. Prog. Ser. 47, 249-258.

Innamorati, M., Mori, M., Lazzara, L., Nuccio, C., Lici, M., Vanucci, S., 1990. Ecology of phytoplankton. In: Nat. Sci. Com. Ant. Ocean. Camp. 1987-88, Data Rep. I, Genova, $161-238$.

Innamorati, M., Lazzara, L., Massi, M., Mori, G., Nuccio, C., Saggiomo, E.V., 1992. Indagine sulla biomassa fitoplanctonica nel Mare di Ross in relazione ai fattori ambientali. In: Gallardo, V.A., Ferretti, O., Moyano, H.I. (Eds.), Atti Seminario Internazionale Oceanografia in Antartide. ENEA-Progetto Antartide-Italia, 235-252.

Lessard, E.J., Swift, E., 1986. Dinoflagellates from the North Atlantic classified as phototrophic or heterotrophic by epifluorescence microscopy. J. Plankton Res. 8, 1209-1215.

Longhurst, A.R., 1991. Role of the marine biosphere in the global carbon cycle. Limnol. Oceanogr. 36 (8), 1057-1526.

Magazzù, G., Decembrini, F., 1992. I risultati di produzione primaria delle crociere oceanografiche 1987-1988 e 19891990 del Programma Nazionale di Ricerche in Antartide. In: Gallardo, V.A., Ferretti, O., Moyano, H.I. (Eds.), Atti Seminario Internazionale Oceanografia in Antartide. ENEA-Progetto Antartide-Italia, 273-284.

Nuccio, C., Innamorati, M., Lazzara, L. and Mori, G., 1992. Popolamenti fitoplanctonici nella Baia di Terranova, Mare di Ross. In: Gallardo, V.A., Ferretti, O., Moyano, H.I. (Eds.), Atti Seminario Internazionale Oceanografia in Antartide. ENEA-Progetto Antartide-Italia, 253-262.

Pierce, R.W., Turner, J.T., 1992. Ecology of planktonic ciliates in marine food webs. Rev. Aquat. Sci. 6 (2), 139-181.

Putt, M., Stoecker, D.K., 1989. An experimentally determined carbon: volume ratio for marine oligotrichous ciliates from estuarine and coastal waters. Limnol. Oceanogr. 34, 10971103.

Rassoulzadegan, F., Laval-Peuto, M., Sheldon, R.W., 1988. Partitioning of the food ration of marine ciliates between pico- and nanoplankton. Hydrobiology 159, 75-88.

Stocchino, C., Manzella, G.M.R., 1991. Analisi delle correnti marine di Baia Terra Nova (Mare di Ross-Antartide). C.N.R. Area di ricerca di Genova, 1-55.

Utermöhl, H., 1958. Zur Vervollkommung der quantitativen Phytoplankton-Methodik. Mitt. Int. Ver. Theor. Angew. Limn. 9, 38.

Verity, P.G., Langdon, C., 1984. Relationships between lorica volume, carbon, nitrogen, and ATP contents of tintinnids in Narragansett Bay. J. Plankton Res. 6, 859-868. 